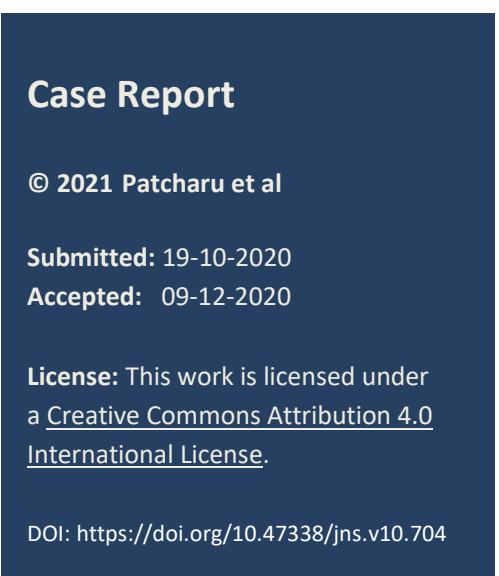

\title{
Phytobezoar causing intestinal obstruction in a neonate: A case report
}

\author{
Ravi Patcharu, ${ }^{1}$ Karunesh Chand, ${ }^{* 1}$ Badal Parikh, ${ }^{2}$
}

1 Department of Pediatric Surgery, Army Hospital (Research \& Referral), New Delhi 110010, India

2 Department of Anesthesiology and Critical Care, Army Hospital (Research \& Referral), New Delhi 110010,

India

Correspondence*: Karunesh Chand, Department of Pediatric Surgery, Army Hospital (Research \& Referral), New Delhi 110010, India. E-mail: karuneshshahi@gmail.com

\section{KEYWORDS}

Neonate,

Intestinal obstruction

Phytobezoar

Jatakarma

\section{ABSTRACT}

Background: Phytobezoars are concretions of non-digestible vegetative matter in the gastrointestinal tract and are a rare cause of intestinal obstruction in children.

Case presentation: We report a case of intestinal obstruction in a 2-day-old neonate with no specific radiological features pointing to any common etiology. On exploratory laparotomy, a swollen raisin was found impacted in the ileum causing intestinal obstruction. The history taken in retrospect revealed that the elder sibling had witnessed her father perform a traditional ritual of putting a drop of honey into the mouth of the newborn and she imitated the same with a raisin, which led to the obstruction.

Conclusion: A careful detailed history of local traditional rituals is at times, the most important pointer towards the etiology of a clinical condition. The basic clinical skill of history taking is still very important, despite the availability of advanced radiological investigations.

\section{INTRODUCTION}

Neonatal intestinal obstruction is commonly caused by small bowel atresia, intestinal malrotation, Hirschsprung's disease, or meconium ileus, with subtle differences in clinical and radiological findings. Foreign bodies in the intestinal lumen of newborns are very uncommon events. In older children, most of the foreign bodies are swallowed accidentally.[1] In most instances, a foreign body does not cause complete obstruction, and after it has passed through the esophagus, it will pass the entire gastrointestinal tract.[2] However, there is almost no information about intestinal foreign bodies in newborns. [3]

Intestinal bezoars are a rare cause of intestinal obstruction in children. It is even rarer in a newborn. Bezoar as the etiology of intestinal obstruction is not usually considered in the neonatal and early infancy. Herein, we report a case of intestinal obstruction in a neonate caused by a raisin impacted in the distal ileum.

\section{CASE REPORT}

A term male baby, with a birth weight of $3.2 \mathrm{~kg}$, was born by normal vaginal delivery to a gravida-3 mother.
Feeds were started and the baby was well till about 30 hours of life when the child developed vomiting which was initially nonbilious, and later turned bilious in nature. The child was reviewed by a Pediatric Surgeon at another center, where the child was admitted and started on IV antibiotics and IV fluids. Upper GI contrast study was done which showed dilated proximal small bowel loops and absence of distal bowel gas. The patient was referred to our center; on arrival, the patient's heart rate was 140 beats per minute, and respiratory rate of 42 breaths per minute.

Oxygen saturation was $97 \%$ on ambient air and nasogastric output was bilious. The abdomen was distended, soft, the hernial sites were normal, and the anal opening was normally located. On auscultation, bowel sounds were exaggerated. A supine radiograph of the abdomen showed dilated central small bowel loops but no air shadows in the pelvis (Fig.1). Ultrasound of the abdomen showed dilated gas-filled bowel loops and Doppler showed normal orientation of superior mesenteric vessels. Laboratory examination showed a normal $\mathrm{CBC}$ and serum electrolytes. 


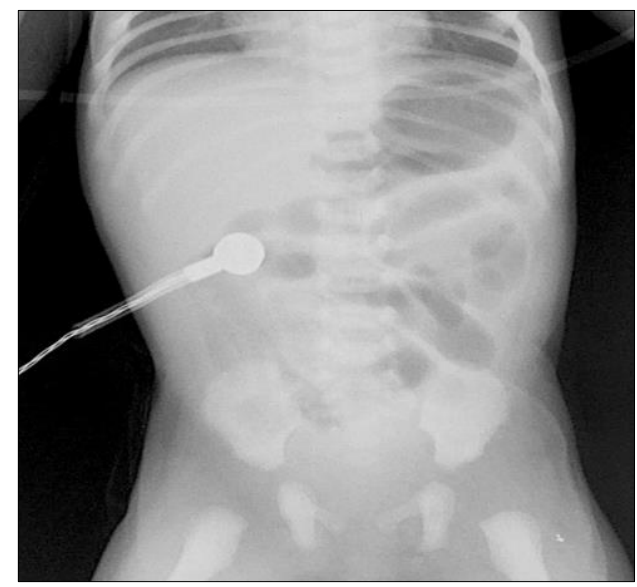

Figure 1: Abdominal radiograph showing dilated small bowel loops and absence of gas shadows in the pelvis.

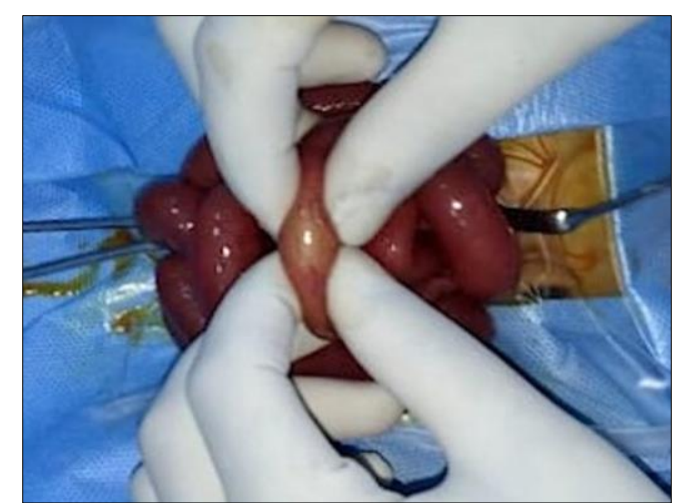

Figure 2: Intraluminal soft globular foreign body impacted in the distal ileum.

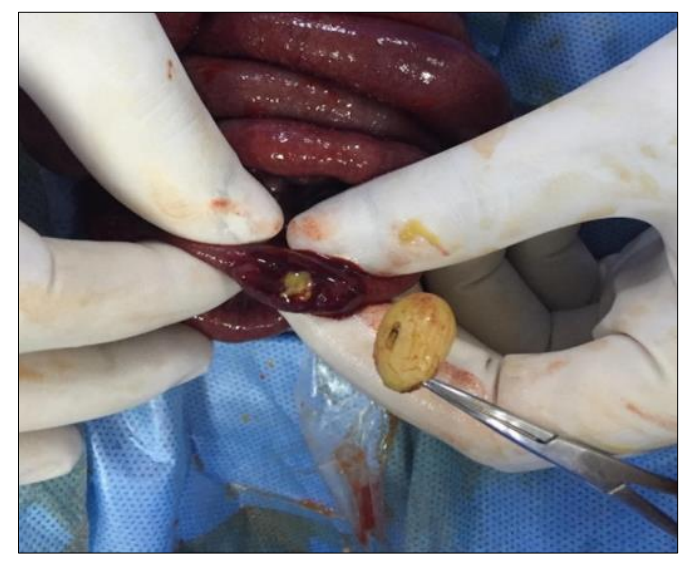

Figure 3: Enterotomy revealing a swollen raisin impacted in the distal ileum

A diagnosis of intestinal obstruction was made; however, the clinical and radiological features did not point at any likely etiology. As the patient had acute intestinal obstruction, he was taken up for emergency exploratory laparotomy. The intraoperative findings showed dilated small bowel loops with an intraluminal soft, globular foreign body impacted in the distal ileum (Fig.2). The bowel was opened longitudinally over the foreign body which was found to be a swollen raisin that had imbibed fluid and swollen up and was completely obstructing the narrow lumen of the terminal ileum (Fig.3). The raisin was removed and the enterotomy was closed. On re-inquiry, it was found that the elder sister who was five years old, playfully put a raisin into the mouth of the newborn, which went unnoticed by the parents. Postoperative recovery was uneventful, and the patient was discharged in good clinical condition. The child was initially on 3 monthly follow up for one year. During the last follow-up, he was 2 years old, asymptomatic, and had normal developmental milestones.

\section{DISCUSSION}

Our patient developed features of intestinal obstruction on the second day of life, though the baby passed meconium spontaneously on the first day of life and tolerated breastfeeding initially, thus minimizing the possibility of congenital causes of neonatal intestinal obstruction. The abdominal radiograph showed dilated central small bowel loops but the absence of gas shadows in the pelvis indicating a small bowel obstruction. The malrotation was also ruled out in our patient based on history, $\mathrm{x}$-ray, and doppler findings.

The operative findings were surprising and brought forth an unusual cause of the neonatal intestinal obstruction. The newborn Hindu ritual of putting a drop of honey and ghee (clarified butter) is known as "Jatakarma".[4] The elder sibling tried to imitate the father with a raisin and, it is likely that a small raisin was swallowed easily by the neonate without choking. During the time taken for its transit in the gut, the raisin had imbibed fluids and swollen up to cause intestinal obstruction.

The occurrence of a swallowed foreign body in a neonate is rare with only a few cases reported. If the incident has not been witnessed and the ingested object is radiolucent, the diagnosis of foreign body ingestion can be very tricky in neonates.[5] Patients and their families are rarely aware of swallowed foreign bodies, which could cause complete intestinal obstruction or even intestinal perforation. [4] The literature on ingested foreign bodies in neonates is limited to case reports which have been tabulated in Table 1 . The most-reported esophageal foreign body in a neonate is a swallowed endotracheal tube (ETT).[5] Other ingested foreign bodies reported are stones, button, nail, thumbtack, marble, bean, etc. as mentioned in Table 1. [3],[5-21] Sharma et al, [9] in 1993 reported a case of a cotton ball phytobezoar in a neonate, wherein the neonate accidentally swallowed a cotton ball which was being used to administer sweetened water as part of a ritual in north India.

Bezoars are rare in neonates. Based on their composition, they are classified into phytobezoars (concretions of vegetable matters), trichobezoars (hair), lactobezoars (concentrated milk formulas), pharmacobezoars (drugs), and food bolus bezoars. Phytobezoars are con- 
cretions of indigestible fibers derived from ingested vegetables and fruits. They have been ascribed to the ingestion of mainly persimmon, coconut fibers, celery, skin, and stems of grapes, prunes, raisins, leek, mallow, and wild beets.[22] The mechanism of phytobezoar formation from plant substances is probably mechanical and depends upon the insoluble and indigestible fiber content.[22] They are commoner in adults and rarely reported in the pediatric age group.[23] The most common site of formation is the stomach and it is not unusual to find parts of phytobezoar in the small bowel.[24] Primary small bowel phytobezoars are rare and are almost always obstructive. They usually become impacted in the narrowest portion of the small bowel, the commonest site being the terminal ileum followed by the jejunum. [25] In our patient, the raisin had gradually swollen up and got impacted in the terminal ileum causing the obstruction, which could be discovered only after an enterotomy.

Table 1: Literature on ingested foreign bodies and bezoars in neonates.

\begin{tabular}{|c|c|c|c|c|c|c|c|}
\hline $\begin{array}{c}\text { Sr } \\
\#\end{array}$ & Author & Year & Age & $\begin{array}{l}\text { Foreign } \\
\text { body }\end{array}$ & Location & Clinical presentation & Country \\
\hline 1 & $\begin{array}{l}\text { Dogruyol H } \\
\text { et al [6] }\end{array}$ & 1989 & 4 days & Bean & Esophagus & Vomiting & Turkey \\
\hline 2 & $\begin{array}{l}\text { Chowdhury } \\
\text { CR et al [7] }\end{array}$ & 1992 & 3 weeks & Button & $\begin{array}{l}\text { Esophagus C7 } \\
\text { level }\end{array}$ & $\begin{array}{l}\text { Episode of cyanosis followed by a } \\
\text { persistent cough }\end{array}$ & Germany \\
\hline 3 & $\begin{array}{l}\text { Thapa BR } \\
\text { et al [8] }\end{array}$ & 1993 & 13 days & Stone & Upper esophagus & $\begin{array}{l}\text { Elder sibling inserted. Symptoms } \\
\text { mimicked TEF }\end{array}$ & India \\
\hline 4 & $\begin{array}{l}\text { Sharma LK } \\
\text { et al [9] }\end{array}$ & 1993 & 6 days & Cotton ball & Lower esophagus & $\begin{array}{c}\text { Frothy salivation, simulating } \\
\text { Esophageal atresia. Diagnosed on } \\
\text { esophagoscopy }\end{array}$ & India \\
\hline 5 & $\begin{array}{c}\text { Tander et al } \\
{[3]}\end{array}$ & 1999 & 4 days & Fresh grape & Ileocecal junction & Small bowel obstruction & Turkey \\
\hline 6 & $\begin{array}{l}\text { Al-Odaidan } \\
\mathrm{N} \text { et al }[10]\end{array}$ & 2000 & 20 days & Thumbtack & Upper esophagus & $\begin{array}{l}\text { Difficulty in feeding, fever. Elder } \\
\text { sibling probably inserted }\end{array}$ & $\begin{array}{l}\text { Saudi } \\
\text { Arabia }\end{array}$ \\
\hline 7 & $\begin{array}{l}\text { Tasneem } Z \\
\text { et al [5] }\end{array}$ & 2004 & $\begin{array}{l}3 \text { days } \\
2 \text { days }\end{array}$ & $\begin{array}{l}\text { Finger ring } \\
\text { ETT }\end{array}$ & $\begin{array}{l}\text { Upper esophagus } \\
\text { Stomach }\end{array}$ & $\begin{array}{l}\text { Witnessed accidental ingestion } \\
\text { Premature baby, accidental } \\
\text { esophageal intubation }\end{array}$ & Pakistan \\
\hline 8 & $\begin{array}{l}\text { Zameer M } \\
\text { et al [11] }\end{array}$ & 2010 & 25 days & Stone & $\begin{array}{l}\text { Cervical } \\
\text { esophagus }\end{array}$ & $\begin{array}{l}\text { Elder sibling playfully inserted a } \\
\text { stone }\end{array}$ & India \\
\hline 9 & $\begin{array}{l}\text { Tarnowska } \\
\text { et al [12] }\end{array}$ & 2010 & 8 days & $\begin{array}{l}\text { Cotton } \\
\text { buds }\end{array}$ & Lower esophagus & Esophageal atresia & Poland \\
\hline 10 & $\begin{array}{l}\text { B Mirza et } \\
\text { al [13] }\end{array}$ & 2010 & 2 days & $\begin{array}{l}\text { Silicone } \\
\text { suction } \\
\text { catheter }\end{array}$ & Esophagus & $\begin{array}{c}\text { Witnessed accidental ingestion } \\
\text { during suctioning }\end{array}$ & Pakistan \\
\hline 11 & $\begin{array}{c}\text { Ranju } \\
\text { Singh et al } \\
{[14]}\end{array}$ & 2012 & 12 days & $\begin{array}{l}\text { Button } \\
\text { battery }\end{array}$ & Upper esophagus & Vomiting, drooling of saliva & India \\
\hline 12 & $\begin{array}{c}\text { Baldev } \\
\text { Singh et al } \\
{[15]}\end{array}$ & 2013 & 30 days & $\begin{array}{l}\text { Glass } \\
\text { marble }\end{array}$ & Upper esophagus & Vomiting, drooling of saliva & India \\
\hline 13 & $\begin{array}{l}\text { Ehtesham } \\
\text { HS et al } \\
{[16]}\end{array}$ & 2015 & 21 days & Marble & $\begin{array}{l}\text { Cervical } \\
\text { esophagus }\end{array}$ & $\begin{array}{c}\text { Respiratory distress due to } \\
\text { compression of trachea by marble }\end{array}$ & India \\
\hline 14 & $\begin{array}{l}\text { Kazi et al } \\
{[17]}\end{array}$ & 2015 & 7 days & Nail & Upper esophagus & $\begin{array}{c}\text { History of elder sibling putting a } \\
\text { nail in the neonate's mouth to } \\
\text { keep him quiet }\end{array}$ & Pakistan \\
\hline 15 & $\begin{array}{l}\text { Srikanth KP } \\
\text { et al [18] }\end{array}$ & 2016 & $\begin{array}{l}4 \text { days } \\
20 \text { days }\end{array}$ & $\begin{array}{l}\text { Medicine } \\
\text { dropper } \\
\text { Anklet } \\
\text { hangout }\end{array}$ & $\begin{array}{l}\text { Mid esophagus } \\
\text { Upper esophagus }\end{array}$ & $\begin{array}{l}\text { Witnessed accidental swallowing } \\
\text { Simulating Esophageal atresia }\end{array}$ & India \\
\hline 16 & $\begin{array}{l}\text { Prashant } \\
\text { Patil et al } \\
{[19]}\end{array}$ & 2016 & 5 days & Finger ring & Cricopharynx & Right pneumothorax & India \\
\hline 17 & $\begin{array}{l}\text { Vijay Pujar } \\
\text { et al [20] }\end{array}$ & 2019 & 6 days & $\begin{array}{l}\text { Betel nut } \\
\text { pieces }\end{array}$ & Mid esophagus & $\begin{array}{c}\text { Homicidal, Simulating Esophageal } \\
\text { atresia }\end{array}$ & India \\
\hline 18 & $\begin{array}{l}\text { Md Kamran } \\
\text { et al [21] }\end{array}$ & 2020 & 25 days & $\begin{array}{l}\text { Pencil } \\
\text { spring }\end{array}$ & Cecum & Cecal perforation & Pakistan \\
\hline
\end{tabular}


To conclude, rare causes of neonatal intestinal obstruction need to be considered when the clinicoradiological features do not point to a specific etiology. Knowledge of local traditional practices and rituals is at times the most important pointer towards the etiology of a clinical condition. The basic clinical skill of history taking is still so important despite the availability of advanced radiological investigations.

Acknowledgements: Nil

\section{REFERENCES}

1. Groff III DB, Welch KJ, Randolph JG. Foreign bodies and bezoars. Pediatr Surg. 1986; 2:4.

2. Webb WA. Management of foreign bodies of the upper gastrointestinal tract: Update. Gastrointest Endosc. 1995; 41:39-51.

3. Tander B, Baskin D, Mutlu G, Sever N, Bulut M. An unusual foreign body in the bowel lumen causing obstruction in a neonate. J Pediatr Surg. 1999; 34:128990. Available from: https://doi.org/10.1016/S00223468(99)90173-2.

4. Jyothy KB, Sheshagiri S, Patel KS, Rajagopala S. A critical appraisal on Swarnaprashana in children. Ayu. 2014; 35:361-5. Available from: https://doi.org / 10.4103/0974-8520.158978.

5. Tasneem Z, Khan MA, Uddin N. Esophageal foreign body in neonates. J Pak Med Assoc. 2004; 54:159-61. Available from: https://www.jpma.org.pk/article-details/369.

6. Doğruyol H, Gürpinar AN. A foreign body in a four-dayold infant's esophagus: a case of negligence. Turkish $\mathrm{J}$ Pediatr. 1989; 31:163-6.

7. Chowdhury CR, Bricknell MC, MacIver D. Oesophageal foreign body: an unusual cause of respiratory symptoms in a three-week-old baby. J Laryngol Otol. 1992; 106:556-7. Available from: https://doi.org/10.1017 /S0022215100120134.

8. Thapa BR, Kaur BW, Nagi B, Dilawari JB. Unusual foreign body (stone) in the esophagus of a neonate mimicking tracheoesophageal fistula. Ind Pediatr. 1993; 30:943.

9. Sharma LK, Sharma A. Cotton-ball phytobezoar simulating oesophageal atresia. Indian J Pediatr. 1993; 60:709-10. Available from: https://doi.org/ 10.1007/BF02821742.

10. Al-Odaidan N, Amu OD, Fahmy M, Al-Khalifa H, Ghazal SS. An unusual case of an impacted esophageal foreign body. Saudi Med J. 2000; 21:202-3.

11. Zameer M, Kanojia RP, Thapa BR, Rao KN. Foreign body oesophagus in a neonate: a common occurrence at an uncommon age. Afr J Pediatr Surg. 2010; 7:114. Available from: https://www.afrjpaedsurg.org/text .asp?2010/7/2/114/62853.

12. Tarnowska A, Roik D, Chmielik LP, Brzewski M. An unusual oesophageal foreign body in neonate - case report. Pol J Radiol. 2010; 75:58-60.

13. Mirza B, Saleem M, Sheikh A. Broken piece of silicone suction catheter in upper alimentary tract of a neonate. APSP $J$ Case Rep. 2010; 1:8. Available from: https://www.ncbi.nlm.nih.gov/pmc/articles/PMC341 $7984 /$.
Conflict of Interest: Authors have no conflict of interest.

Source of Support: Nil

Consent to Publication: Author(s) declared taking informed written consent for the publication of clinical photographs/material (if any used), from the legal guardian of the patient with an understanding that every effort will be made to conceal the identity of the patient, however it cannot be guaranteed.

Author Contributions: Author(s) declared to fulfil authorship criteria as devised by ICMJE and approved the final version.

14. Singh R, Pandit C, Gupta D, Vajifdar H. Foreign body esophagus in a neonate: Unusual age and unusual presentation. J Anaesthesiol Clin Pharmacol. 2012; 28:258. Available from: https://dx.doi.org/10.4103 \%2F0970-9185.94915.

15. Singh B, Bhagat S, Kataria G, Kaur G, Singh R. Unusual esophageal twin foreign body (glass marble) in a neonate. Online J Health Allied Sci. 2013; 12:21. Available from: http://cogprints.org/9169/1/2013-221.pdf.

16. Ehtesham HS, Beg MH, Haseen A, Akhtar S. Marble in oesophagus of neonate: A unique and unprecedented case report. Int J Pediatr Child Health. 2015; 3:31-4.

17. Kazi SG, Habib MI, Afzal B, Khan IQ, Siddiqui E, Aftab M. Nail as a foreign body in a neonate, an unusual presentation at an unusual age. J Pak Med Assoc.2015; 65:315-6.

18. Srikanth KP, Thapa BR, Chadha V, Menon J. Trivial and fatal complications of esophageal foreign bodies in neonates. J Clin Neonatol. 2016; 5:109-11. Available from: https: doi.org/10.4103/2249-4847.161718.

19. Patil PS, Kothari P, Gupta A, Kekre G, Dikshit V, Kamble $\mathrm{R}$, et al. Pneumothorax in a neonate after foreign body ingestion. J Neonatal Surg. 2016; 5:23.

20. Pujar VC, Joshi SS, Dhaded SM. Unusual cause of esophageal obstruction in a neonate presenting as esophageal atresia. J Neonatal Surg. 2013; 2:47.

21. Kamran M, Khan SU, Saleem M, Iqbal A, Hashim I, Khan JI, et al. Pencil spring ingestion in a neonate-a rare occurrence with cecal perforation: A case report. $J$ Pediatr Adolesc Surg. 2020; 1:50-2. Available from: https://doi.org/10.46831/jpas.v1i1.11.

22. Teng HC, Nawawi O, Ng KL, Yik YI. Phytobezoar: an unusual cause of intestinal obstruction. Biomed Imag Interv J. 2005; 1:e4. Available from: https://doi.org /10.2349/biij.1.1.e4.

23. Kadian Y, Singla RK, Parihar D. Primary small bowel phytobezoar in children-a report of two cases. CIB Tech J Surg. 2012; 1:4-8.

24. Quercioli A, Dallegri F, Ottonello L, Montecucco F, Borgonovo $\mathrm{G}$. Intestinal radiation-induced stricture favours small bowel obstruction by phytobezoar: report of a case. Gastroenterol Res Prac. 2009; 2009. Available from: https://doi.org/10.1155/2009/482039.

25. Teo $\mathrm{M}$, Wong $\mathrm{CH}$, Chui $\mathrm{CH}$. Food bolus - an uncommon cause of small intestinal obstruction. Aust $\mathrm{N} \mathrm{Z} \mathrm{J}$ Surg. 2003; 73 . 